\title{
An Intercultural Immersion Experience in Foreign Language Classroom
}

\author{
Shu-hua Hsueh*, Ruey-ming Shih \\ Fuzhou University of International Studies and Trade No. 28, Yuhuan Road, Shouzhan New District, Changle \\ District, Fujian Province, PR China
}

*Corresponding Authors: Shu-hua Hsueh, Fuzhou University of International Studies and Trade No. 28, Yuhuan Road, Shouzhan New District, Changle District, Fuiian Province, PR China

\begin{abstract}
With the impact of internet, our world has been changed dramatically in all aspects such as science, technology, economy and social system. In the world of Internet, we interact frequently with people from various countries and cultures via multi-media. Foreign languageteachingplays a bridging role in transporting and communicating all of the people from different cultures. In this article the author aims to highlight the intercultural communication in the foreign language teaching by applying language immersion approach to foreign language classroom. Findings indicated the positive attitude and benefits of intercultural immersion in foreign language teaching and learning by implementing a video with Mexican culture. Furthermore, this article intends to encourage foreign language teachers to employ more intercultural classroom activities with the language immersion approach.
\end{abstract}

Keywords: foreign language, intercultural communication, language immersion, target language

\section{INTRODUCTION}

Nowadays, the main purpose of learning a foreign language is not only to learn how to speak the language fluently but also to learn how to communicate properly with the people of the target language. Consequently, the communicative competence is globally emphasized in language teaching and learning. Traditionally, in Eastern countries foreign language teachers focus on linguistic teaching such as vocabulary, grammar while paying little attention on the culture issues. Kuang(2007) indicated that the main reason for Chinese students fail to communicate effectively is that Chinese culture is different from that of English-speaking countries and hence English teachers should equip students with the knowledge of cultural background and improve their cross-cultural communication abilities. So, culture is not a single term in language teaching but a whole part of language teaching. It is not limited to the literature, poem and arts, yet should include all aspects of culture in the target language. To achieve the purpose of involving culture of the target language into the language teaching, immersion teaching approach is strongly recommended and implemented as it is the most efficient way to familiarize with a new language. With the advanced communication and transportation, language learning is no longer limited to textbooks or teacher-led learning in classroom, students can travel or take short-term language courses to immerse themselves in the country of the target language. This culture embedded language learning phenomenon also greatly has been affecting the language teaching approaches in the classrooms of schools.

\section{TEACHING APPROACH}

\subsection{Intercultural Learning, Language Immersion and Immersive Environment}

Teaching culture can establish and develop the culture awareness and sensitivity of the target language. It's important to realize how to incorporate pedagogical aspects of culture into foreign language teaching context. Schulz (2007) proposed that the teaching of intercultural competence should include developing awareness of variables that affect communicative interactions, recognizing stereotypes and evaluating them, and developing awareness of types of causes for cultural misunderstandings between members of different cultures. (Schulz, 2007: p. 18, cited in Moeller et al.2015).Therefore, language immersion is believed to be a good approach to involve different cultures into second language learning.Genesee (1985) mentioned that second language immersion pro- 
grams were first applied in 1965 in Canada and instituted in regard to the concerns of a group of English-speaking parents in Quebec. The feature of immersion programs at that time was the use of French to teach regular schools subjects. Since then, more and more similar immersion programs have been instituted in the US. This approach is very distinctive from conventional second language methods which focus on the rules of grammatical or vocabularies memorizing. It is proficiency-driven and concentrates on the needs of real communication in the classroom. Students in all types of immersion programs have been found to achieve significantly higher levels of proficiency in all aspects of French than students receiving conventional French second-language instruction (Genesee, 1985).Sharma (2017) defines that immersion as learning a new language in the most natural way possible and the instruction is given in the target language. Sadly, it is unlikely for everyone to travel to the country of target language or attend immersion programs. If not for the career, family and financial concerns, students can immerse themselves into the foreign language learning. Seven practical ways are recommended to create an immersive environment at home for learning Spanish as a target language.

[1] Change the language of your phone to Spanish.

[2] Listen to Spanish radio online.

[3] Watch a movie in Spanish.

[4] Listen to a Spanish podcast.

[5] Look up a recipe in Spanish and cook the food.

[6] Exercise with the Comprehensive Spanish course package 15-30 minutes every day.

[7] Meet up regularly with a tutor or a language buddy.

As in a teaching context of a traditional college, in this paper the author employed the [3] Watch a movie in Spanish to open up students' imaginations in the world of target language where sociocultural awarenessis raised through seeing, listening and discussing a video.

\section{INTERCULTURAL IMMERSION EXPERIENCE IN FL CLASSROOM}

This intercultural immersion classroom experience occurred to the students who are Spanish major freshmen in China. As foreign language beginners, they tended to be very nervous and intimated but also very excited to learn the new foreign language- Spanish. Since this is the first semester for them to study Spanish, watching a video will comfort their mind and boost their motivation to learn Spanish. As Hill (1999) stated that through watching videos students' learning motivation and confidence will be established because of the contextualization of the story. In particular, he suggested that teachers have appropriate teaching strategy to carry out and immerse video watching into classroom activity. Likewise, using drama can launch students' imaginations while involving them into the complexity of socio-cultural context. Thus, motivating studentsto another language will become an easier task for teachers(Rothwell, 2011). Therefore, watchingMexican movie will be a good incentive to compare the culture of Mexico comparing with Chinese traditional culture.

The class planning and activities for theSpanish language class are as the following.

\subsection{Lesson Plan}

\section{Title: Building cultural awareness through movie watching.}

Participants: College students (Spanish major Freshmen)

\section{Objectives:}

Students acquires Spanish vocabularies and culture while easily linkingMexican cultureto Chinese Tomb Sweeping Day.

Students will be able to immerse in the Mexican culture during and after viewing the movie Coco (2017).

\subsection{Movie Summary}

The best part of this movie "Coco" (2017) is its portrayal of a detailed representation of Mexican culture and Day of the Dead.The movie Coco's main character is Miguel who is a little boy and always 
gets fascinated to become a musician. But his family is strongly against his musical dream because his great-great-grandfather left his wife and child behind into pursuit a musician career. Miguel's family developed a hatred towards anything that was associated with music. However, he still managed to fulfill his dream by participating in a talent competition "Day of the Dead", a traditional Mexican festival that celebrates people's ancestors or be loved ones that have died in the past.The movie highlights the biggest fear that no one will remember them after they pass away. "Coco" addresses on the fear of the death and encourages people to live in the present while discussing Mexican social culture in depth.

\subsection{Teacher Activated Prior Knowledge by Guiding Students to Watch the Movie "Coco"}

Tomb Sweeping Day is an annual Chinese holiday on the first day of the fifth solar term in the traditional Chinese lunisolar calendar (April 4 or 5). It is one of the three most important festivals in Chinese society. On this day families gather to honor their ancestors as well as sweep their tombs.Normally, people bring flowers and offerings to the tombswhere they honor the memory of their ancestors. It's a very important family activity. Before watching this movie, teacher had a short conversation with students to guide their anticipation to this video.

Teacher : What do you do on Tomb Sweeping Day with your family?

StudentA : It is a very important day in our families. We bring offerings to the place of our ancestors' tomb and clean the tomb's surroundings.

Teacher : Why should we do that?

StudentB : We do want to remember our ancestors and pray for peace.

Teacher : OK, very good. Then, we are going to watch this Mexican movie introducing Day of the Dead which is similar to our Tomb Sweeping Day, but the way they do is very distinctive. Let's watch this movie and try to understand what they do and how they think.

\subsection{After Watching the Video, Our Discussions Are As Below.}

Teacher : How do you feel about this movie?

Student C : It's so touched and very interesting. The spirit of Day of the Death is similar to Chinese Tomb Sweeping Day.

Student D : But the way, their celebration is not the same as ours.

Teacher : Very good. And now please fill out these questions about viewing this movie.

\section{SURVEY OF Class ACTIVITY WITH MOVIE WATCHING}

The survey consisted of three parts: (1) background information, (2) attitude toward the movie, (3) experience after watching the movie. Students were asked to respond to the statements listed below, of which Q1 to Q6 are in the form of Likert questionnaires by ranking their level of satisfaction on a scale from 1 (strongly agree) to 7 (strongly disagree).

\subsection{Background Information is shown in Table 1. (AB is the name code of the person being tested)}

The questionnaire "Survey of Your experience after viewing the Mexican movieCoco" was distributed to 61 students enrolled in Spanish major courses at the beginning of the 2019 fall semester.

Table1. Profile of Students

\begin{tabular}{|l|l|l|l|}
\hline Name & Gender & Education & Freshman \\
\hline A & male & college & 10 \\
\hline B & Female & college & 51 \\
\hline
\end{tabular}

\subsection{Attitude Toward the Movie}

The survey was divided into five sections to analyze students' preferences for the film and the expression of the plot style, namely 1 . The film characters, 2 . The film plot, 3 . The film music, 4 . The film culture, and 5. The film voiceover as a reference for future teaching choices. The results of the questionnaire survey showed that 13 students chose storytelling, 8 students chose stylistic style, 2 students chose expressing means, 23 students chose visual effects and 15 students chose character building. 
And the result of the film was 38 choices with a reasonable plot but unexpected outcome, 8 choices with a reasonable plot but unexpected outcome, 15 choices with a reasonable plot and unexpected outcome, and 0 choices with a reasonable plot and unexpected outcome. Explaining the preference of subjects at this stage for a biased plot style is that the plot was reasonable but the results were unexpected 38 students chose it, $62 \%$ of the total number of students, and the image focused on the effect nearly $38 \%$.

\subsection{Experience after Viewing the Movie.}

Q1. Watching the COCO video has increased my interest in learning Spanish.

Q2. In terms of language learning, watching Spanish videos increases the vocabulary power of Spanish.

Q3. In terms of language learning, watching Spanish videos, the oral dialogues can be used in my everyday life.

Q4. In terms of language learning, watching Spanish videos can enhance the effectiveness of Spanish language learning.

Q5. In terms of language learning, watching Spanish language videos can enhance your understanding of Mexican culture.

Q6. Spanish movies can be used as useful teaching materials. This will enhance my interest on Spanish learning.

Table2. Students' learning experience toward the movie "Coco" (N61)

\begin{tabular}{|l|l|l|l|l|l|l|l|}
\hline Questions & $\begin{array}{l}\text { Strongly } \\
\text { Agree }\end{array}$ & $\begin{array}{l}\text { Very } \\
\text { Agree }\end{array}$ & $\begin{array}{l}\text { Moderately } \\
\text { Agree }\end{array}$ & Agree & Moderately Disagree & $\begin{array}{l}\text { very } \\
\text { Disagree }\end{array}$ & $\begin{array}{l}\text { Strongly } \\
\text { Disagree }\end{array}$ \\
\hline \multirow{2}{*}{$1 \# / \%$} & 20 & 14 & 18 & 8 & 1 & 0 & 0 \\
\cline { 2 - 9 } & $33 \%$ & $23 \%$ & $30 \%$ & $13 \%$ & $2 \%$ & 0 & 0 \\
\hline \multirow{2}{*}{$2 \# / \%$} & 20 & 8 & 20 & 12 & 1 & 0 & 0 \\
\cline { 2 - 9 } & $33 \%$ & $13 \%$ & $33 \%$ & $20 \%$ & $2 \%$ & 0 & 0 \\
\hline \multirow{2}{*}{$3 \# / \%$} & 17 & 11 & 19 & 11 & 1 & 1 & 0 \\
\hline \multirow{2}{*}{$4 \# / \%$} & $28 \%$ & $18 \%$ & $31 \%$ & $18 \%$ & $3 \%$ & $2 \%$ & 0 \\
\hline \multirow{2}{*}{$5 \# / \%$} & 17 & 12 & 18 & 12 & 1 & 1 & 0 \\
\cline { 2 - 9 } & $28 \%$ & $20 \%$ & $30 \%$ & $20 \%$ & $2 \%$ & $2 \%$ & 0 \\
\hline \multirow{2}{*}{$6 \# / \%$} & 18 & 13 & 22 & 7 & 1 & 0 & 0 \\
\hline & $30 \%$ & $21 \%$ & $36 \%$ & $11 \%$ & $2 \%$ & $0 \%$ & 0 \\
\hline
\end{tabular}

(1\# - $6 \#$ is the code of the questions being asked)

The present study adopted the (Xu, 1998) appropriate dependence on the Table 2 format content median as a consideration weighting above 0.50 , which facilitates the discussion of the importance of the composition and suggestions.

\subsection{Results of the Questionnaire Demonstrated That:}

1. In question $1,56 \%$ of the students chose "Strongly agree" and "very agree" thatwatchingCoco film increased their interest on learning Spanish.

2. In questions $\mathbf{2}$ and $\mathbf{3}, 46 \%$ of the students thought that watching the video increasedtheirvocabulary power and they can use the dialogues of the film into their everyday life.

3. In question 4, above $48 \%$ of the students "Strongly agree" and "very agree" that movie watching can enhance the effectiveness of Spanish learning;

4. In question 5, more than $51 \%$ of the students thought that the film Coco helps them understand the Mexican culture.

5. In question 6, 61\% of the students "Strongly agree" and "very agree"supported to use film as a teaching material in classrooms to increase their interest on learning Spanish. 


\subsection{Data Analysis}

This survey was an investigation on the correlation between the viewing of cultural films and learning experience in FL classrooms. Analysis of this questionnaire revealed three significant findings. First, in question 1 to 3 , less than $50 \%$ of the students agreed on the increase of vocabulary power, daily use dialogues and effectiveness of the video. The possible reason is that they are Spanish beginners with limited words and sentences. To improve this situation, the author will prepare the vocabulary and sentences related to the video in advance and teach them to students before watching the video, which will facilitate learning while watching the video. Second, in question 5, more than $51 \%$ of the students almost totally agreed that the movie Coco enhanced their understanding of Mexican culture. This proved that cultural understanding and building requires a lively storytelling on the film shelf to make an impression.Introducing foreign culture through video is more interesting and allows students to be more integrated into the storyline, and relatively more accepting of the target language culture. The third finding was that although in practice the proportional allocation of lesson time is not easily achieved, students were strongly (61\%) in favor of the inclusion of videos as teaching materials in curriculum, which is very constructive for foreign language teaching. Whether they are an integral part of the school curriculum or supplementary teaching materials, video watching with their special classroom arrangement would help to develop an effective learning environment. Foreign language teachers can design film-related activities to motivate their students.

\section{CONCLUSION}

Watching movies can relieve foreign language beginners' nervousness and fear in classroom. In particular, the culture' element will embrace students the theme of the story and immerse themselves in the culture of target language. Through watching this video, students found Mexican culture is similar to traditional Chinese culture. Therefore, they feel closer to this target language and have more courage and confidence to learn how to speak out some basic Spanish vocabularies and simple dialogues.Being a foreign language teacher in China, the author encountered the problems of teaching foreign language without mentioning much culture. In the foreign language classroom, teachers still concentrate on teaching lexical, phonological and grammar rules from the perspective of tight class schedule. The survey findingsproved that students are very interested in target language learning by viewing cultural video. We hope to encourage foreign language teachers to widely involve students in imaginative worlds and immerse themselves in a sensibility dimension in order to fulfill the goal of intercultural communication.

\section{REFERENCES}

[1] Brown, H. D. (1994). Principles of Language Learning and Teaching (3rd edn)Englewood Cliffs, NJ: Prentice Hall Regents.

[2] Byram, M. (1997). Teaching and Assessing Intercultural Communicative Competence. Clevedon, UK: Multilingual Matters.

[3] Coco (2017) Mexican Movie. https://www.facebook.com/pg/PixarCoco/photos/

[4] Chan, W.M. and Klayklueng S. (2018). Critical and Cultural Awareness and Identity

[5] Development: Insights from a Short-Term Thai Language Immersion, National University of Singapore, Singapore Electronic Journal of Foreign Language Teaching, Vol. 15, Suppl. 1, pp. 129-147 @ Centre for Language Studies National University of Singapore

[6] Foley J., Thompson L., (2003) Language Learning: A Lifelong Process,Distributed in the United States of America by Oxford University Press Inc., New York

[7] Genesee F. (1985). Second Language Learning Through Immersion: A Review of U.S. Programs. Review of Educational Research Winter, 1985, Vol. 55, No. 4, Pp. 541-561

[8] Hawkar A. A. (2014). Does Teaching Language Automatically Entail Teaching Culture? International Journal of Language and Linguistics. Vol. 2, No. 4, pp. 258-262.

[9] Hill, B. (1999). Video in language learning. InfoTech 4. London: Centre for Information on Language Learning.

[10] Hsin,C.(2008).Language and culture in foreign language teaching http://www.leeds.ac.uk/educol/documen ts/178899.pdf

[11] Jiang, W. (2000). The Relationship between Culture and Language. ELT Journal, 54(4), 328- 334. 
[12] José AldemarÁlvarez Valencia (2014) Developing the intercultural perspective in foreign language teaching in Colombia: a review of six journals, Language and Intercultural Communication, 14:2, 226-244, DOI: $10.1080 / 14708477.2014 .896922$

[13] Komorowska, H. (2006). Intercultural competence in ELT syllabus and materials design. ScriptaNeophilologicaPosnaniensia vol. VIII: 59-83.

[14] Kuang, J.F (2007). Developing students' cultural awareness through foreign language Teaching. Sino-US English Teaching, ISSN1539-8072, USA, Dec. 2007, Volume 4, No.12 (Serial No.48)

[15] Kumagai, Y. (1994). The Effects of Culture on Language Learning and Ways of Communication: The Japanese Case. Master's Capstone Projects. 80. Retrieved from https://scholarworks.umass.edu/cie_capstones/80

[16] Marczak, M. (2010).New Trends in Teaching Language and Culture. In Komorowska, H. \&Aleksandrowicz-Pędich, L. (eds.) Coping with Diversity. Szkoły Psychologii Społecznej, pp. 13-28.

[17] Mingyu, Z. (2019). Correlation Study on Grammatical Sensitivity Test Indexes in Intercultural Communication.Revista de cercetareșiintervențiesocială,vol.65,pp.26

[18] Moeller, Aleidine Kramer and Catalano, Theresa, (2015). Foreign Language Teaching and Learning. Faculty Publications: Department of Teaching, Learning and Teacher Education. 200.

[19] Rothwell, J. (2011) Bodies and language: process drama and intercultural languagelearning in a beginner language classroom. The Journal of Applied Theatre and Performance Vol. 16, No. 4, November 2011, 575-594

[20] Sharma Heidi (2017) Learning a Language through Immersion. November 17, https://www.worddive.com/ blog/learning-a-language-through-immersion/

[21] Shemshadsaraw, Z. G. (2012) Developing Cultural Awareness in Foreign Language Teaching.www.ccsenet.org/elt English Language Teaching Vol. 5, No. 3; Published by Canadian Center of Science and Education 95

[22] Sun, Li. (2013) Culture Teaching in Foreign Language Teaching. ISSN 1799-2591Theory and Practice in Language Studies, Vol. 3, No. 2,pp. 371-375

[23] Tomalin, B., \&Stempleski, S. (1993). Cultural awareness. Oxford: Oxford University Press.

[24] Tomlinson, B., \&Musuhara, H. (2004). Developing cultural awareness. MET, 13(1), 1-7

[25] Ugur R. C. (2012). WCES 2012 Intercultural communicative competence in ELT Procedia - Social and Behavioral Sciences. 46 (2012) 3445 - 3449

[26] Xue J. (2014). Theory and Practice in Language Studies. Vol. 4, No. 7, pp. 1492-1498, (C 2014 AcademyPublisher Manufactured in Finland.

[27] Xu Cunhe (1998). The Fuzzy Delphi Analytic Hierarchy Process. Journal of Fuzzy Systems 4:1 pp. 59-72

\section{AUTHORS' BIOGRAPHY}

Shu-hua Hsueh is an instructor of Fuzhou University of International Studies and Trade. She graduated from University of Alabama at Birmingham (USA) with Master Degree at Education Department. Her research field focuses on Language acquisition.

Citation: Shu-hua Hsueh, Ruey-ming Shih, "An Intercultural Immersion Experience in Foreign Language Classroom” International Journal on Studies in English Language and Literature (IJSELL), vol 8, no. 10, 2020, pp. 18-23. doi: https://doi.org/10.20431/2347-3134.0810003.

Copyright: (c) 2020 Authors. This is an open-access article distributed under the terms of the Creative Commons Attribution License, which permits unrestricted use, distribution, and reproduction in any medium, provided the original author and source are credited. 